\title{
Evaluation of dried bread waste as feedstuff for growing crossbred pigs
}

\author{
Ajay Kumar ${ }^{1}$, Biswajit Roy², G. P. Lakhani² and A. Jain²
}

1. Department of Livestock Production and Management, UP Pt. Deen Dayal Upadhyaya Veterinary Science University (DUVASU), Mathura, Uttar Pradesh, India; 2. Department of Livestock Production and Management, College of Veterinary Science and Animal Husbandry, Nanaji Deshmukh Veterinary Science University, Jabalpur, Madhya Pradesh, India. Corresponding author: Biswajit Roy, e-mail: drbiswajitroy@gmail.com, AK: drajayvet1010@gmail.com, GPL: lakhani_gandhi@yahoo.com, AJ: jainaklank@yahoo.com

Received: 06-05-2014, Revised: 01-08-2014, Accepted: 05-08-2014, Published online: 19-09-2014

doi: 10.14202/vetworld.2014.698-701. How to cite this article: Kumar A, Roy B, Lakhani GP, Jain A (2014) Evaluation of dried bread waste as feedstuff for growing crossbred pigs, Veterinary World 7(9): 698-701.

\begin{abstract}
Aim: The aim was to investigate the effect of bread waste feeding on feed intake, utilization and growth performance of crossbred pigs and to evaluate the economics of bread waste feeding.

Materials and Methods: The study was conducted for a period of 3 months (December, 2012-March, 2013). Large White Yorkshire crosses (LWY X Desi) were included in the study. A total of 24 weaned crossbred growing pigs were randomly assigned to four different groups, with six animals in each group. The experimental animals were fed as per their body weight following Indian Council of Agricultural Research requirements. They were fed twice a day according to schedule at 9:00 am and 3:00 pm. The water was kept available to animals round the clock. The cost of the experimental diets was calculated based on the existing price of the ingredients during the experimental period. Samples of feed were collected for analysis of proximate principles as per Association of Official Analytical Chemist. Body weight of all animals was recorded fortnightly basis in the morning before feeding with the use of platform type electronic weighing balance. Feed conversion ratio (FCR) and protein conversion ration was calculated by using a standard formula. Data were analyzed, using one-way analysis of variance (ANOVA). Means showing significant differences in the ANOVA table were compared using the Duncan multiple range test.

Results: Crude protein content $(\%)$ of the diets was $16.01 \pm 0.02,16.13 \pm 0.02,16.14 \pm 0.02,16.04 \pm 0.02,16.08 \pm 0.02$ and $12.72 \pm 0.03$, respectively for the G1, G2, G3 and G4, groups. Proximate compositions (\%) of diets used in the experiment were not significantly different. Digestibility coefficients of all the nutrients were significantly varied among the experimental groups. Daily feed intake was significantly $(\mathrm{p}<0.05)$ varied among the groups. Average daily gain $(\mathrm{kg} / \mathrm{pig} / \mathrm{day})$ were significantly $(\mathrm{p}<0.01)$ higher in group G2 (0.377). FCR was significantly $(\mathrm{p}<0.01)$ higher in the G2 group (4.35).
\end{abstract}

Conclusion: Bread waste can economically supplement up to $50 \%$ to the diet of crossbred growing pigs.

Keywords: bread waste, crossbred pigs, economics, feed intake, growth performance.

\section{I ntroduction}

Feeding constitutes the greatest cost (about 70\%) in raising pigs and affects the pig's performance and sustainability of the sector. Pigs are monogastric and omnivorous. More than 60\% deficiency in concentrate feed sources is a threat to the pig industry, which compete directly with human for grains [1]. Feed manufacturers and livestock producers are facing problems as prices of grains and oil cakes are increasing day by day. Therefore, researchers always search for alternate feed resources to replace the conventional ingredients used for the animal production. Alternate feed resources include various organic by product from the food processing industry which do not have any definite use. The feeding of food waste or garbage to swine and other livestock is a common practice throughout the world and is often concentrated around metropolitan centers where it is available at bulk.

These wastes may be fed to other livestock species, but has most often been used as a source of feed for

Copyright: The authors. This article is an open access article licensed under the terms of the Creative Commons Attributin License (http:// creative commons.org/licenses/by/2.0) which permits unrestricted use, distribution and reproduction in any medium, provided the work is properly cited. swine [2]. Among the food industry by product, bread waste from the bakery is an important one. Bakery waste includes bread, cookies, crackers and other confectionaries. Large numbers of bread factories are operated in the urban and peri-urban areas, and they produce a sizable amount of bread waste during processing and marketing of the bread. Waste bread has no other definite use; it can be economically used in the pig ration, as pig can accept a wide range of feed items. Results from different feeding trials with different classes of animals, i.e., cattle [3], sheep [4], goats [5], pigs [6], rabbit [7] and chickens [8] indicated that bakery waste was a satisfactory feed ingredient for animals.

There is a paucity of information regarding the use of bread waste in the diet of crossbred pigs. Keeping in view of the above facts, the study was designed to investigate the effect of bread waste feeding on feed intake, utilization and growth performance of crossbred pigs and to evaluate the economics of bread waste feeding.

\section{Materials and Methods}

\section{Ethical approval}

The experiment followed the guidelines of Institutional Animal Ethics Committee. 
Proposed work was conducted at pig farm of All India Coordinated Research Project on pigs, livestock farm, Adhartal, College of Veterinary Science and A.H., Nanaji Deshmukh Veterinary Science University, Jabalpur (M.P.). The study was conducted for a period of 3 months (December, 2012-March, 2013). No mortality was recorded during the entire experimental period. Large White Yorkshire crosses (LWY X Desi) were included in the study. A total of 24 weaned crossbred growing pigs of both sexes were selected. The pigs were randomly assigned to four different groups, with six animals in each group (Table-1). The pre-experimental period of 15 days was allowed to get the experimental animals adjusted before the actual start of the experiment. The experimental animals were fed as per their body weight following Indian Council of Agricultural Research [9] requirements. They were fed twice daily according to schedule at 9:00 am and 3:00 pm. The water was kept available to animals round the clock. The cost of the experimental diets was calculated based on the existing price of the ingredients during the experimental period (Table-2).

Samples of feed were collected for analysis of proximate principles viz. dry matter (DM), crude protein (CP), ether extract (EE), crude fiber (CF), nitrogen-free extract (NFE), and total ash by the standard methods of Association of Official Analytical Chemist (AOAC) [10]. Body weight of all animals was recorded fortnightly basis in the morning before feeding with the use of platform type electronic weighing balance. Feed conversion ratio (FCR) and protein conversion ration were calculated by using a standard formula. At the end of the experiment digestion trial for 3 days

Table-1: Gross composition (\%) and rate of concentrate mixture used in the experiment.

\begin{tabular}{lcccc}
\hline Ingredients & \multicolumn{4}{c}{ Concentrate mixture } \\
\cline { 2 - 5 } & $\mathbf{1}$ & $\mathbf{2}$ & $\mathbf{3}$ & $\mathbf{4}$ \\
\hline Maize & 45.00 & 45.00 & 33.00 & 15.00 \\
Wheat bran & 24.00 & 21.00 & 30.00 & 29.00 \\
Rice polish & 12.00 & 11.00 & 8.00 & 7.00 \\
GNC & 11.00 & 15.00 & 20.00 & 32.00 \\
Fish meal & 6.00 & 6.00 & 7.00 & 15.00 \\
Mineral mixture & 1.00 & 1.00 & 1.00 & 1.00 \\
Salt & 1.00 & 1.00 & 1.00 & 1.00 \\
Total & 100.00 & 100.00 & 100.00 & 100.00 \\
Rate (Rs.)/Quintal & 1525.86 & 1576.34 & 1636.51 & 1886.29
\end{tabular}

Rate of waste bread @ Rs.790/kg, GNC=General nutrition corporation

Table-2: Grouping of animals, their diet and cost of diet.

\begin{tabular}{llc}
\hline Groups & Diets & Cost(Rs.)/ Quintal \\
\hline G1 & $\begin{array}{l}\text { Concentrate mixture-1 } \\
\text { G2 }\end{array}$ & $\begin{array}{l}\text { Concentrate mixture-2 (75\%)+ } \\
\text { Bread waste (25\%) }\end{array}$ \\
G3 & $\begin{array}{l}\text { Concentrate mixture-3 (50\%)+ } \\
\text { Bread waste (50\%) }\end{array}$ & 1379.76 \\
& $\begin{array}{l}\text { Concentrate mixture-4 (25\%)+ } \\
\text { Gread waste (75\%) }\end{array}$ & 1064.07 \\
\hline
\end{tabular}

was conducted. Feed and fecal samples were analyzed by the standard methods of AOAC [10].

\section{Statistical analysis}

Data were analyzed, using one-way analysis of variance (ANOVA) described by Snedecor and Cochran [11]. To study the effect of bread waste feeding on various parameters, the following model was used.

$$
\mathrm{Y}_{\mathrm{ij}}=\mu+\mathrm{B}_{\mathrm{j}}+\mathrm{e}_{\mathrm{ij}}
$$

$\mathrm{Y}_{\mathrm{ij}}=$ Observation under the $\mathrm{i}^{\text {th }}$ group

$\mu=$ Overall mean

$\mathrm{B}_{\mathrm{i}}=$ Fixed effect of $\mathrm{i}^{\text {th }}$ group ( $\mathrm{i}=1,2,3$ and 4$)$

$\mathrm{e}_{\mathrm{ij}}=$ Random error, which is assumed to be normally and independently distributed with zero mean and constant variance $\sigma^{2}$ e.

Means showing significant differences in the ANOVA table were compared using the Duncan multiple range test [12].

\section{Results and Discussion}

Proximate composition of experimental diets is depicted in Table-3. Proximate compositions like DM, CP, EE, CF, NFE and ash were 93.25\%, 12.52\%, $8.45 \%, 2.87 \%, 71.51 \%$ and $4.65 \%$, respectively for the dried bread waste. Proximate compositions (\%) of diets used in the experiment were not significantly different except CP. Digestibility coefficients of individual nutrients have been depicted in Table- 4 . Digestibility coefficients of all the nutrients were significantly $(p<0.05)$ varied among the experimental groups.

Daily feed intake is presented in Table-5. Overall daily feed intake was significantly $(p<0.05)$ varied among the groups. Highest daily feed intake (kg/pig) was observed in the G3 group (1.647 \pm 0.060$)$. It was also observed in the present study that as the inclusion of bread waste in the diet increases above $50 \%$ level, the feed intake starts declining. Similar observation also found in the case of daily DM intake. Average feed intake on the basis of per cent body weight was not significantly varied among the groups. Average daily protein intake $(\mathrm{kg} / \mathrm{pig})$ of crossbred growing pigs were also significantly $(\mathrm{p}<0.05)$ varied among the experimental groups. Present study clearly indicated that as the bread waste inclusion above $50 \%$ in the diet, all types of intakes are reduced.

Average daily gain (ADG) of crossbred growing pigs was presented in Table-5. Overall ADG (kg/pig) over the entire experimental period was $0.371,0.377$, 0.375 and 0.273 , respectively for the G1, G2, G3 and G4 groups. Statistical analysis of the parameter revealed that they were significantly $(\mathrm{p}<0.01)$ different. Highest ADG (kg/pig) was observed in group G2 (0.377).

Feed conversion efficiency of the experimental groups over the entire experimental period is depicted in Table-5. The average feed efficiency in entire experimental period in different groups was 
Table-3: Proximate composition (\%) of diets used in different groups.

\begin{tabular}{lcccrr}
\hline Groups & DM & CP & CF & EE & Ash \\
\hline G1 & $93.79 \pm 0.11$ & $16.01 \pm 0.02$ & $3.44 \pm 0.04$ & $3.59 \pm 0.06$ & $69.19 \pm 0.12$ \\
G2 & $94.34 \pm 0.20$ & $16.13 \pm 0.02$ & $3.14 \pm 0.01$ & $4.16 \pm 0.04$ & $69.23 \pm 0.15$ \\
G3 & $95.37 \pm 0.25$ & $16.14 \pm 0.02$ & $3.23 \pm 0.07$ & $5.54 \pm 0.04$ & $67.35 \pm 0.03$ \\
G4 & $95.04 \pm 0.14$ & $16.04 \pm 0.02$ & $3.07 \pm 0.01$ & $5.60 \pm 0.12$ & $66.01 \pm 0.15$ \\
\hline
\end{tabular}

$\mathrm{DM}=$ Dry matter, $\mathrm{CP}=$ Crude protein, $\mathrm{EE}=$ Ether extract, $\mathrm{CF}=$ Crude fiber, $\mathrm{NFE}=$ Nitrogen-free extract

Table-4: Digestibility coefficient (\%) of diets used in different groups.

\begin{tabular}{lccccc}
\hline Groups & DM & CP & CF & EE & NFE \\
\hline G1 & $83.54 \pm 1.25^{\mathrm{a}}$ & $95.21 \pm 2.21^{\mathrm{a}}$ & $87.15 \pm 1.84^{\mathrm{a}}$ & $85.22 \pm 2.74^{\mathrm{a}}$ & $78.65 \pm 1.94^{\mathrm{a}}$ \\
G2 & $84.31 \pm 1.62^{\mathrm{a}}$ & $96.11 \pm 1.82^{\mathrm{a}}$ & $86.14 \pm 1.45^{\mathrm{a}}$ & $84.11 \pm 2.21^{\mathrm{a}}$ & $76.12 \pm 1.91^{\mathrm{a}}$ \\
G3 & $82.21 \pm 1.11^{\mathrm{a}}$ & $94.25 \pm 2.01^{\mathrm{a}}$ & $85.32 \pm 1.47^{\mathrm{a}}$ & $82.11 \pm 2.14^{\mathrm{a}}$ & $75.35 \pm 1.98^{\mathrm{a}}$ \\
G4 & $79.31 \pm 1.24^{\mathrm{b}}$ & $92.85 \pm 1.87^{\mathrm{b}}$ & $81.44 \pm 1.75^{\mathrm{b}}$ & $79.21 \pm 2.32^{\mathrm{b}}$ & $70.11 \pm 1.87^{\mathrm{b}}$ \\
\hline
\end{tabular}

Means bearing different superscripts within same column differ significantly (ab, $p<0.05$ ). $D M=D r y$ matter, $C P=C r u d e$ protein, $\mathrm{EE}=$ Ether extract, $\mathrm{CF}=$ Crude fiber, NFE=Nitrogen-free extract

Table-5: Effect of bread waste feeding on feed intake, feed conversion efficiency, ADG of growing crossbred pigs.

\begin{tabular}{lcccc}
\hline Groups & G1 & G2 & G3 & G4 \\
\hline Daily feed intake (kg/pig) & $1.613 \pm 0.062$ & $1.636 \pm 0.068$ & $1.647 \pm 0.060$ & $1.392 \pm 0.049$ \\
Daily dry matter intake (kg/pig) & $1.513 \pm 0.058$ & $1.547 \pm 0.065$ & $1.562 \pm 0.056$ & $1.327 \pm 0.047$ \\
Average feed intake (\% of body weight) & $4.11 \pm 0.23$ & $4.17 \pm 0.19$ & $4.29 \pm 0.22$ & $3.92 \pm 0.21$ \\
Average daily protein intake (kg/pig) & $0.258^{\mathrm{a}} \pm 0.010$ & $0.264^{\mathrm{a}} \pm 0.011$ & $0.265^{\mathrm{a}} \pm 0.009$ & $0.223^{\mathrm{b}} \pm 0.007$ \\
FCR & $4.36^{\mathrm{A}} \pm 0.03$ & $4.35^{\mathrm{A}} \pm 0.01$ & $4.41^{\mathrm{A}} \pm 0.02$ & $5.12^{\mathrm{B}} \pm 0.01$ \\
ADG (kg/pig) & $0.371^{\mathrm{A}} \pm 0.015$ & $0.377^{\mathrm{A}} \pm 0.016$ & $0.375^{\mathrm{A}} \pm 0.014$ & $0.273^{\mathrm{B}} \pm 0.010$ \\
\hline
\end{tabular}

Means bearing different superscripts within same row differ significantly ( ${ }^{a b}, p<0.05,{ }^{A B}, p<0.01$ ), $F C R=F e e d$ conversion ratio, $A D G=$ Average daily gain

4.36, 4.35, 4.41 and 5.12, respectively for the G1, G2, G3 and G4 groups. Overall FCR was significantly $(\mathrm{p}<0.01)$ varied among the experimental groups. Highest FCR was found in the G2 group (4.35). The result of the present study again indicated that the FCR values were not significantly different among the G1, G2 and G3 groups, whereas significantly higher value was found in G4 group. FCR value indicated that how efficiently the feedstuffs are utilized for the production purpose.

In the present study, higher body weight gain was observed in the G2 group where $25 \%$ bread waste was added to the diet. In accordance with the present study, Sirtori et al. [13] reported higher ADG in the bread waste supplemented groups. In contrast, Kwak and Kang [14] reported that neither the body weight gain nor the ADG was affected in pigs maintained on food waste mixture and that the feed efficiency decreased when larger amounts of the foodwaste mixture were incorporated into the diet. Thus, the growth rate was severely affected. This might be reflected in the feed efficiency which was significantly lower. Paola et al. [15] reported that the voluntary feed intake of sows supplemented with bakery waste was $10 \%$ lower than that of the control group, although, productive performances of the treated sows were not different from those of the control group. In the present study, mild form of constipation was found in the G4 group, where more than 50\% bread waste was included in the diet. As bread waste contains less fiber [16] which may cause constipation, and the animals are maintained in confinement, where pigs did not have any access to other sources of fiber. Besides this, the feeding preference of pigs is varied depending on the type of food material. This may be the reason of low feed intake in the G4 group, where $75 \%$ bread waste was included in the diet. Chae et al. [17] reported that the feed consumption, weight gain, and ADG decreased in pigs maintained on a diet of $40 \%$ dried food waste. Similarly, Iwamoto [18] reported significantly lower ADG in the breadcrumbs supplemented group than in the control group.

\section{Conclusion}

On the basis of the findings of the present study, it could be concluded that bread waste can be added up to $50 \%$ to the growing crossbred pig ration without affecting growth performance. Feed cost ( ) per $\mathrm{kg}$ body weight gain could be reduced up to $20.45 \%$ in comparison to the conventional concentrate based diet. Price of the waste bread is approximately 52\% of the price of the maize. Therefore, if bread can be purchased for $52 \%$ or less of the price of maize, then it may be economical.

\section{Authors' Contributions}

BR and GPL designed the experiment, AK conducted sample collection and performed the experiment under supervision of BR. Manuscript preparation was supervised, reviewed and edited by BR and AJ. All authors read and approved the final manuscript. 


\section{Acknowledgments}

The authors are thankful to the Dean, College of Veterinary Science and Animal Husbandry, Jabalpur, NDVSU, Jabalpur for providing necessary funds and facilities to carry out the research.

\section{Competing I nterests} interests.

The authors declare that they have no competing

\section{References}

1. NRC on Pig. (2011) Annual Progress Report. National Research Centre on Pigs, ICAR, Rani, Guwahati, Assam. p 1-4.

2. Westendorf, M.L., Schuler, T. and Zirkle, E.W. (1999) Nutritional quality of recycled food plate waste in diets fed to swine. Prof. Anim. Sci., 15(2): 106-111.

3. Passini, R., Spers, A. and Lucci, C.S. (2001) Effects of partial replacement of corn by bakery waste in the diet on performance of Holstein steers. Pesqui Agropecu. Bras, 36(4): 689-694.

4. Obeidat, B.S., Haddad, S.G., Titi, H.H., Abu Ishmais, M.A. and Telfah, B.T. (2012) Performance of nursing Awassi ewes fed different levels of bread by-product. Asian-Aus. J. Anim. Sci., 25(8): 1132-1137.

5. Haddad, S.G. and Ereifej, K.I. (2004) Substituting bread by-product for barley grain in fattening diets for Baladi kids. Asian-Aus. J. Anim. Sci., 17(5): 629-632.

6. Takahashi, T., Kohira, K., Horinouchi, S., Iwakiri, M. and Irie, M. (2012) Effect of feeding level of eco-feed mainly composed of bread from box lunch factory on pig performance, carcass characteristics and pork quality. J. Warm. Reg. Soc. Anim. Sci., 55(1): 33-40.

7. Al-Shami, S.A. and Mohammed, T.A. (2009) Effect of replacement of barley grains by wasted bread crumbs or rejected date on growth performance and carcass trait of growing rabbit. Pak. J. Nutr., 8: 635-641.

8. Adeyemo, G.O., Oni, O.R. and Longe, O.G. (2013) Effect of dietary biscuit waste on performance and carcass characteristics of broilers. Food. Sci. Qual Manage. 12. Available from: http://www.iiste.org/Journals/index.php/FSQM/article/download/4266/4335 Accessed on 25/04/2014.

9. ICAR. (1998) Nutrient Requirement of Domestic Animals. Indian Council of Agricultural Research, New Delhi.

10. AOAC. (1995) Official Method of Analysis. $6^{\text {th }}$ ed. Association of Official Analytical Chemist, Washington, D.C.

11. Snedecor, G.W. and Cochran, W.G. (1994) Statistical Methods. $7^{\text {th }}$ ed. Oxford and IBH Publishing Co., New Delhi.

12. Steel, R.G.D. and Torrie, J.H. (1980). Principles and Procedures of Statistics. A Biometrical Approach. $2^{\text {nd }}$ ed. McGraw Hill Book Co., NewYork, NY, USA.

13. Sirtori, F., Acciaioli, A. and Pianaccioli, L. (2007) Effect of use of bread in fattening of Cinta Senese pig. Ita. J. Anim. Sci., 6(1): 719-721.

14. Kwak, W.S. and Kang, J.S. (2005) Effect of feeding food waste-broiler litter and bakery by-product mixture to pigs. Bioresour. Technol., 97(2): 243-249.

15. Paola, S., Elisabetta, B., Valentino, B., Lina, G. and Alberto, S. (2008) Bakery waste in sows lactation diet. Anim. Fac. Med. Vet. Parm., 28: 201-210.

16. Omole, A.J., Fayenuwo, J.A., Adejuyigbe, A.D. and Popoola, Y.A. (2011) Nutritional evaluation of bread waste as a replacement for maize in the diet of growing snails. J. Cent. Eur. Agric., 12(3): 509-514.

17. Chae, B.J., Choi, S.C., Kim, Y.G., Kim, C.H. and Sohn, K.S. (2000) Effect of feeding dried food waste on growth and nutrient digestibility in growing-finishing pigs. Asian-Aus. J. Anim. Sci., 13(9): 1304-1308.

18. Iwamoto, E. (2005) Effects of breadcrumbs on growth performance and meat quality in pig. J. Anim. Sci., 76(1): $15-22$. 